\title{
Tracer-derived freshwater composition of the Siberian continental shelf and slope following the extreme Arctic summer of 2007
}

\author{
E. Povl Abrahamsen, ${ }^{1}$ Michael P. Meredith, ${ }^{1}$ Kelly Kenison Falkner, ${ }^{2}$ Sinhue Torres-Valdes, ${ }^{3}$ \\ Melanie J. Leng, ${ }^{4}$ Matthew B. Alkire, ${ }^{2}$ Sheldon Bacon, ${ }^{3}$ Seymour W. Laxon, ${ }^{5}$ \\ Igor Polyakov, ${ }^{6}$ and Vladimir Ivanov ${ }^{7}$
}

Received 18 January 2009; revised 20 February 2009; accepted 5 March 2009; published 2 April 2009.

[1] We investigate the freshwater composition of the shelf and slope of the Arctic Ocean north of the New Siberian Islands using geochemical tracer data $\left(\delta^{18} \mathrm{O}, \mathrm{Ba}\right.$, and $\left.\mathrm{PO}_{4}^{*}\right)$ collected following the extreme summer of 2007. We find that the anomalous wind patterns that partly explained the sea ice minimum at this time also led to significant quantities of Pacific-derived surface water in the westernmost part of the Makarov Basin. We also find larger quantities of meteoric water near Lomonosov Ridge than were found in 1995. Dissolved barium is depleted in the upper layers in one region of our study area, probably as a result of biological activity in open waters. Increasingly ice-free conditions compromise the quantitative use of barium as a tracer of river water in the Arctic Ocean. Citation: Abrahamsen, E. P., M. P. Meredith, K. K. Falkner, S. Torres-Valdes, M. J. Leng, M. B. Alkire, S. Bacon, S. W. Laxon, I. Polyakov, and V. Ivanov (2009), Tracer-derived freshwater composition of the Siberian continental shelf and slope following the extreme Arctic summer of 2007, Geophys. Res. Lett., 36, L07602, doi:10.1029/2009GL037341.

\section{Introduction}

[2] During the autumn of 2007 the Arctic Ocean sea ice reached its lowest extent since the 1950s [Stroeve et al., 2008]. In this changing environment, assessing the state of physical and chemical conditions in the Arctic Ocean is now essential. Because of its role in regulating heat fluxes between Atlantic water masses and the sea-ice cover, the cold, fresh halocline is of particular importance [Aagaard et al., 1981]. The Siberian shelves exert a strong influence on the structure of the Arctic halocline through their role in distributing freshwater between the Amundsen and Makarov basins [Steele and Boyd, 1998], and it is known that the pathways for outflow from the shelves are highly dependent on wind patterns, both locally over the shelf [Guay et al., 2001], and over the central Arctic Ocean [Dmitrenko et al.,

\footnotetext{
${ }^{1}$ British Antarctic Survey, Natural Environment Research Council, Cambridge, UK.

${ }^{2}$ College of Oceanic and Atmospheric Science, Oregon State University, Corvallis, Oregon, USA.

${ }^{3}$ National Oceanography Centre, Southampton, UK

${ }^{4}$ NERC Isotope Geosciences Laboratory, British Geological Survey, Keyworth, UK.

${ }^{5}$ Centre for Polar Observations and Modelling, University College London, London, UK.

${ }^{6}$ International Arctic Research Center, University of Alaska Fairbanks, Fairbanks, Alaska, USA.

${ }^{7}$ Scottish Association for Marine Science, Oban, UK.
}

Copyright 2009 by the American Geophysical Union. 0094-8276/09/2009GL037341
2008, and references therein]. The latter wind patterns are often quantified using the vorticity of winds in the central Arctic Ocean. Dmitrenko et al. [2005] found that there was a good correlation between a summer vorticity index (for June-September) and sea surface salinity patterns over the Laptev and East Siberian Seas. Using a summer vorticity index combined with a collection of historical data, Dmitrenko et al. [2008] found that the area northwest of the New Siberian Islands had a significant anticorrelation between freshwater content anomaly and the summer vorticity index.

[3] According to Zhang et al. [2008], anomalous wind patterns contributed to the extreme sea ice minimum of 2007 by causing more ice to exit through Fram Strait than usual, and also forced more Pacific water into the Arctic Ocean. In the Laptev and East Siberian seas, the predominant winds during the summer months (June-September) were easterly (the NCEP reanalysis wind field averaged over these months is shown in Figure 1a).

[4] Here we quantify the freshwater composition of the Siberian shelf and slope during autumn 2007, and discuss the role of the variable winds in determining the flow paths of riverine input. This is important in the context of the extreme Arctic change seen in 2007, in terms of the sensitivity of the region to large-scale change, and its consequences for freshwater delivery to the broader Arctic halocline.

\section{Methods}

[5] In the autumn of 2007, a joint cruise was conducted on $R / V$ Viktor Buynitskiy between the Nansen and Amundsen Basin Observational System (NABOS) project and other working groups including scientists from the Arctic Synoptic Basin-wide Oceanography (ASBO) project. Over three weeks at the end of September and the beginning of October, 71 stations were occupied with CTD (conductivitytemperature-depth) casts. We obtained water samples from 44 stations (see the map in Figure 1a), which were analyzed for dissolved oxygen $\left(\mathrm{O}_{2}\right)$, phosphate $\left(\mathrm{PO}_{4}^{3-}\right)$, barium $(\mathrm{Ba})$, and $\delta^{18} \mathrm{O}$. The study area was ice-free at the time of the cruise.

[6] The CTD used was a Sea-Bird Electronics 19+, fitted with a dissolved oxygen sensor and fluorometer. Water samples were collected at pre-programmed depths on the downcast, with the rosette still in motion. Salinity samples were collected to calibrate the conductivity cell. Dissolved phosphate concentrations were determined using a segmented flow continuous-flow Skalar San ${ }^{\text {plus }}$ autoanalyzer with a limit of detection of $0.03 \mu \mathrm{mol} \mathrm{L}{ }^{-1}$. In addition to the dissolved oxygen sensor attached to the CTD, samples were taken and 

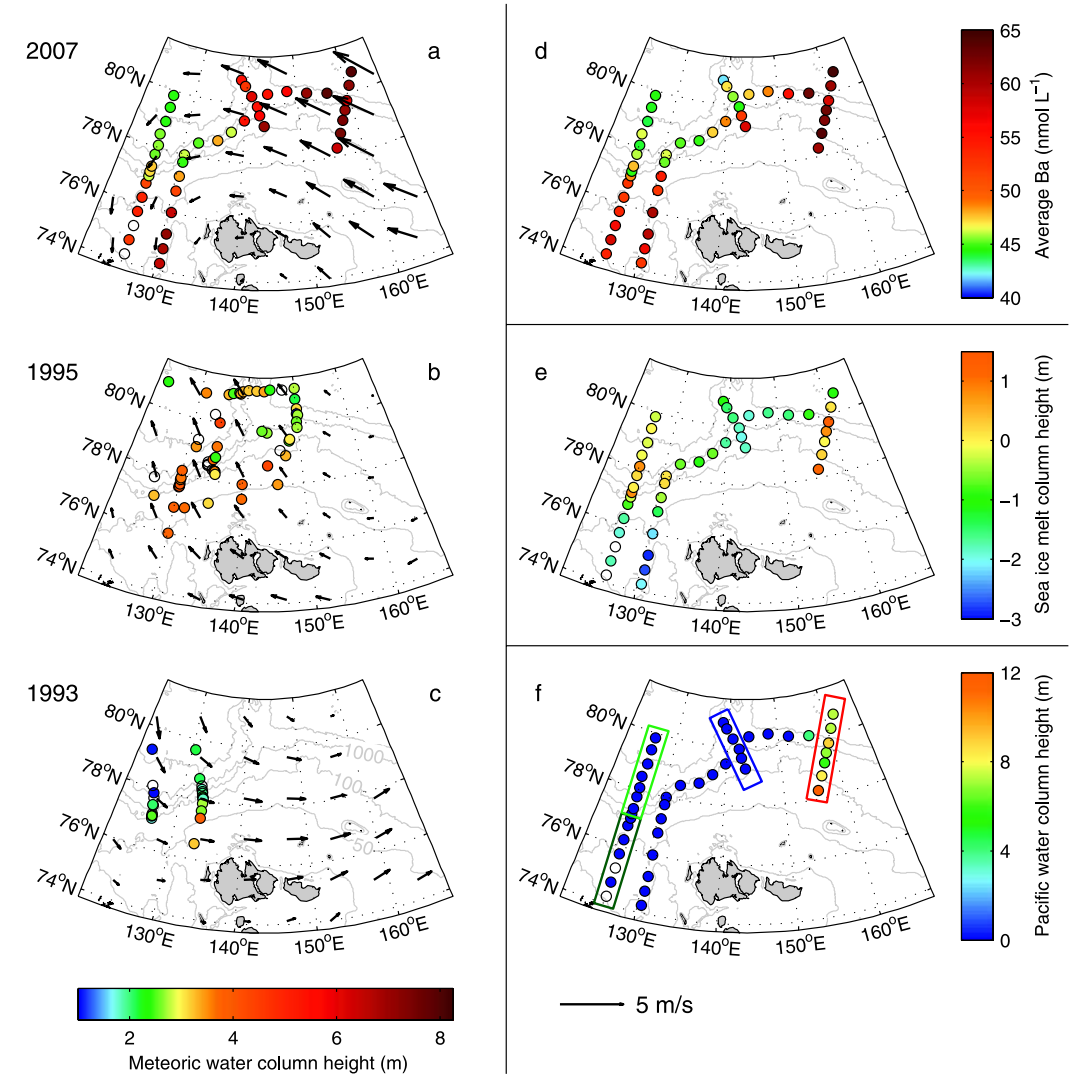

Figure 1. Maps showing the integrated fractions of meteoric water in (a) 2007, (b) 1995, and (c) 1993, respectively, with summer (June-September) wind vectors from the NCEP reanalysis superimposed. (d) Average dissolved barium concentration in 2007. (e) Integrated water mass fractions for sea ice meltwater in 2007. (f) Integrated water mass fractions for Pacific water in 2007-also indicating the positions of sections W/S (dark green), W/N (light green), C (blue), and E (red). All of these plots show data integrated or averaged from the surface to $50 \mathrm{~m}$ depth.

analyzed on board using a Winkler $\Omega$-Metrohm titration unit (794 DMS Titrino) with an amperometric system to determine the end point of the titration. The average offset between the CTD and sample values was $36 \pm 13 \mu \mathrm{mol} \mathrm{kg}^{-1}$, which was added to the CTD values. No attempt was made to calibrate the fluorometer data; hence, data shown here are relative values only.

[7] Dissolved barium was analyzed at Oregon State University using isotope dilution-inductively coupled plasma quadruple mass spectrometry (ICP-MS), similar to the methods used by, e.g., Guay and Falkner [1997]; the precision is estimated to be better than $3 \%$. Samples for $\delta^{18} \mathrm{O}$ were analyzed at the NERC Isotope Geosciences Laboratory, Keyworth, by equilibration with $\mathrm{CO}_{2}$ [Epstein and Mayeda, 1953] using a VG Isoprep 18, with mass spectrometry performed on a VG Sira 10, yielding an average precision of $0.03 \%$ on duplicates of these samples.

\section{Results}

\subsection{Hydrography}

[8] Figure 2 shows hydrographic and geochemical profiles for the upper $100 \mathrm{~m}$. Here we have focused on three sections, indicated on the map in Figure 1f. The western section has the highest salinities at the temperature minimum; this is characteristic of convective lower halocline water [Rudels et al., 1996; Woodgate et al., 2001]. The central section is similar to the western, but temperatures start to increase at lower salinities. The halocline on the eastern section shows marked differences to the central and western sections. While the water directly above the halocline is near the freezing point in the western and central sections, warmer water is present in the eastern section, indicating an advective source of the halocline waters. The halocline is also considerably less steep and deeper in this area. Profiles of fluorescence from the three sections also differ, with uniformly low levels in the western section, a surface maximum in the central section, and a deeper maximum with little fluorescence near the surface in the eastern section.

[9] Dissolved barium values are similar to Atlantic background values in the western section. In the central section, there is a pronounced reduction in barium in the upper $20 \mathrm{~m}$ of the water column, with enhanced levels at depths below, down to $50 \mathrm{~m}$. It will be seen that this is linked to biological processes. In the eastern section, we find elevated levels of barium throughout. These, and low near-surface fluorescence, lead us to conclude that the eastern section is least affected by biological drawdown.

\subsection{Water Mass Balance}

[10] In order to determine the composition of our water samples, we used a four-component mass balance, using salinity, $\delta^{18} \mathrm{O}$, and $\mathrm{PO}_{4}^{*}$, a quasi-conservative tracer based on phosphate and dissolved oxygen, using a method similar to 


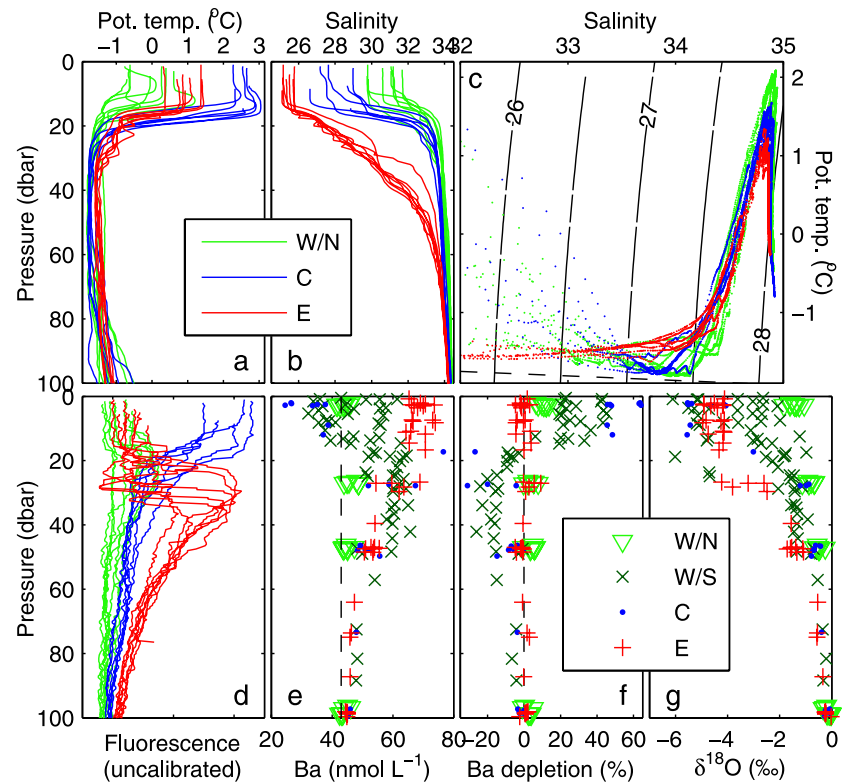

Figure 2. Profiles of (a) potential temperature, (b) salinity, (d) fluorescence, (e) dissolved barium, (f) barium depletion, and $(\mathrm{g}) \delta^{18} \mathrm{O}$ for three sections; Figure $2 \mathrm{c}$ shows the $\theta / \mathrm{S}$ diagram for these stations. The Atlantic end-member value of $43 \mathrm{nmol} \mathrm{L}^{-1}$ is indicated with a dashed line in Figure 2e.

that of Ekwurzel et al. [2001]. This enables us to discriminate between Atlantic and Pacific source waters, sea-ice meltwater, and meteoric freshwater, i.e., river runoff and precipitation.

[11] As we do not have oxygen titration measurements for each water sample, we use the titration values when available, and otherwise we use corrected values from the CTD oxygen sensor. As per Ekwurzel et al. [2001] and Broecker et al. [1998], we use the formula $\mathrm{PO}_{4}^{*}=\mathrm{PO}_{4}^{3-}+$ $\mathrm{O}_{2} / 175-1.95 \mu \mathrm{mol} \mathrm{kg} \mathrm{kg}^{-1}$. We then solve the following system of mass-balance equations:

$$
\begin{gathered}
f_{a}+f_{p}+f_{i}+f_{m}=1 \\
f_{a} \mathrm{~S}_{a}+f_{p} \mathrm{~S}_{p}+f_{i} \mathrm{~S}_{i}+f_{m} \mathrm{~S}_{m}=\mathrm{S} \\
f_{a} \delta^{18} \mathrm{O}_{a}+f_{p} \delta^{18} \mathrm{O}_{p}+f_{i} \delta^{18} \mathrm{O}_{i}+f_{m} \delta^{18} \mathrm{O}_{m}=\delta^{18} \mathrm{O} \\
f_{a} \mathrm{PO}_{4 a}^{*}+f_{p} \mathrm{PO}_{4 p}^{*}+f_{i} \mathrm{PO}_{4 i}^{*}+f_{m} \mathrm{PO}_{4 m}^{*}=\mathrm{PO}_{4}^{*}
\end{gathered}
$$

where $f_{a}$ is the fraction of Atlantic water, $f_{p}$ is Pacific water, $f_{i}$ is sea-ice meltwater (or brine if negative), and $f_{m}$ is meteoric water. If the resulting fraction of Pacific water is negative (because of vanishingly small quantities of Pacific water combined with small inaccuracies in end-members and measurements), a three-component system of equations is solved instead, using just equations (1)-(3) with $f_{p}$ set to zero, giving the same equations as used by Östlund and Hut [1984].

[12] Our end-members are given in Table 1 . These mostly follow Ekwurzel et al. [2001]; however, our Atlantic end- member has been modified to match the lower water masses in our dataset. In addition, our meteoric water has a $\delta^{18} \mathrm{O}$ of $-21 \%$ to reflect that in this region the main runoff we expect to find originates in the Lena and Kolyma rivers [Cooper et al., 2008].

[13] To quantify the effect of using a four-component mass balance as opposed to a three-component mass balance on derived quantities of meteoric water and sea ice meltwater, we have recalculated the water mass fractions without using $\mathrm{PO}_{4}^{*}$; this is the same method as used when Pacific water is not present. For those points where Pacific water is present, we get a mean reduction in the meteoric fraction of 0.006 , with a maximum reduction of 0.03 where most Pacific water is present. The changes in sea ice meltwater fractions are negligible.

[14] Figures 1a, 1e, and 1f show the equivalent water column heights (i.e., integrated fractions) of meteoric water, sea ice meltwater, and Pacific water in the upper $50 \mathrm{~m}$ in 2007. In addition, Figures $1 \mathrm{~b}$ and $1 \mathrm{c}$ show the meteoric water heights calculated using three-component water mass fractions from Polarstern cruises ARK XI/1 and ARK IX/4 in 1995 and 1993, respectively (these $\delta^{18} \mathrm{O}$ and salinity data are available from Schmidt et al. [1999]). In 2007, we found a significant amount of Pacific water in the eastern section, with no Pacific water in the central and western sections. The net sea-ice meltwater height was slightly positive in most of the eastern section and the northern part of the western section, while there was large net brine content in the central section and on the shelf. We would expect net negative seaice melt rates, since more sea ice is formed in this region than melts here [Rigor and Colony, 1997].

[15] In the area covered by the 1993 cruise, meteoric water inventories are similar to those in 2007. However, the 1995 cruise shows a different distribution, with more meteoric water beyond the shelf break in the Amundsen Basin. However, inventories for stations east of $140^{\circ} \mathrm{E}$ and beyond the shelf break are much smaller, averaging $2.7 \mathrm{~m}$, while the average in this area in 2007 was $6.9 \mathrm{~m}$.

\subsection{Depletion of Barium}

[16] Figure 1d shows the spatial distribution of dissolved barium averaged in the top $50 \mathrm{~m}$ of the water column. Unsurprisingly, the pattern of meteoric water thickness in Figure 1a largely resembles the average barium in Figure 1d. The exception to this is the central section, where the barium levels are notably depleted in response to biological activity. We have conducted a quantitative assessment of this removal using the mass balance calculations above. Our barium endmembers for this come from different sources: the Atlantic value is based on our data; the Pacific water value comes from Taylor et al. [2003]; and the sea-ice value is calculated from their formula $\mathrm{S}_{i c e} \times \mathrm{Ba}_{s f c} / \mathrm{S}_{s f c}$, where $\mathrm{Ba}_{s f c}$ and $\mathrm{S}_{s f c}$ are surface barium concentrations and salinities, respectively,

Table 1. Properties of the End-Members Used for Water Mass Balance Calculations

\begin{tabular}{lcccc}
\hline & Salinity & \multicolumn{1}{c}{$\begin{array}{c}\delta^{18} \mathrm{O} \\
(\% 0)\end{array}$} & $\begin{array}{c}\mathrm{PO}_{4}^{*} \\
\left(\mu \mathrm{mol} \mathrm{kg}^{-1}\right)\end{array}$ & $\begin{array}{c}\mathrm{Ba} \\
\left(\mathrm{nmol} \mathrm{L}^{-1}\right)\end{array}$ \\
\hline Atlantic water & 34.9 & 0.25 & 0.7 & 43 \\
Pacific water & 32.7 & -1.1 & 2.4 & 72 \\
Sea-ice meltwater & 4.0 & sfc. +2.6 & 0.4 & 8 \\
Meteoric water & 0.0 & -21.0 & 0.1 & 140 \\
\hline
\end{tabular}


assuming $\mathrm{Ba}_{s f c} \approx 60 \mathrm{nmol} \mathrm{L}^{-1}$ and $\mathrm{S}_{s f c} \approx 30$. To calculate the meteoric barium concentration, we used the values from the section that appears to be least influenced by biological activity (the eastern section) and calculated the expected meteoric barium concentration from

$$
\mathrm{Ba}_{m}=\frac{\mathrm{Ba}-f_{a} \mathrm{Ba}_{a}-f_{p} \mathrm{Ba}_{p}-f_{i} \mathrm{Ba}_{i}}{f_{m}} .
$$

[17] Assuming an uncertainty of 3\% for the barium measurements, 0.02 for $f_{a}, f_{i}$, and $f_{m}, 0.05$ for $f_{p}, 1 \mathrm{nmol} \mathrm{L}^{-1}$ for $\mathrm{Ba}_{a}, 7 \mathrm{nmol} \mathrm{L}{ }^{-1}$ for $\mathrm{Ba}_{p}$, and $2 \mathrm{nmol} \mathrm{L}^{-1}$ for $\mathrm{Ba}_{i}$, respectively, we can also calculate the uncertainty of the resulting estimates of $\mathrm{Ba}_{m}$. The average of these estimates, weighted by the inverse of the uncertainty, is $140 \pm 7 \mathrm{nmol} \mathrm{L}^{-1}$. For comparison, Guay and Falkner [1998] found an effective concentration of $130 \mathrm{nmol} \mathrm{L}^{-1}$ for the Lena and $150 \mathrm{nmol}$ $\mathrm{L}^{-1}$ for the Indigirka, while the Kolyma may have slightly lower values [Cooper et al., 2008].

[18] With these end-members, we can determine the depletion, defined as the fraction of the initial barium concentration $\left(\mathrm{Ba}^{\circ}\right)$ that has been removed (for positive values), or any excess barium found (negative values). The initial barium concentration is calculated from the water mass fractions and end-members in Table 1:

$$
\begin{gathered}
\mathrm{Ba}^{\circ}=f_{a} \mathrm{Ba}_{a}+f_{p} \mathrm{Ba}_{p}+f_{i} \mathrm{Ba}_{i}+f_{m} \mathrm{Ba}_{m} \\
\text { Ba depletion }=\frac{\mathrm{Ba}^{\circ}-\mathrm{Ba}}{\mathrm{Ba}^{\circ}}
\end{gathered}
$$

For our water samples in the three sections, these are plotted in Figure 2e. While the depletion is very close to zero for the eastern section, there is a significant depletion in the central section, and in the southern part of the western section, on the shelf. This is accompanied by an excess of barium at deeper levels. This is consistent with an interpretation that barium is being removed biologically from the upper layers of the ocean, and redissolved at depth [Falkner et al., 1994; Stecher and Kogut, 1999]. The removal observed here in the central section is more pronounced than that observed previously by Falkner et al. [1994], to an extent that the mean barium concentrations in the central section are actually lower than the background Atlantic values, even though the $\delta^{18} \mathrm{O}$ values indicate a substantial meteoric water fraction.

[19] Generally, the surface barium was most depleted in areas where the nitrate was close to zero. This implies that barium mainly is removed at the end of the summer bloom, when nutrients — and especially nitrate - are depleted [Smith and Sakshaug, 1990].

\section{Discussion and Conclusions}

[20] As previously discussed by Guay et al. [2001] and Dmitrenko et al. [2005], the summer hydrography of the Laptev and East Siberian Seas is dominated by the wind patterns over the shelf and over the Arctic Ocean. While winds in 1993 were cyclonic, causing the freshwater plume from the Lena to remain on the shelf, winds in 1995 were offshore, causing a wider spread of riverine waters over the shelf and into the Amundsen Basin. Wind vectors from these years are shown in Figures $1 \mathrm{~b}$ and $1 \mathrm{c}$.

[21] In 2007, winds were cyclonic over the central Arctic; average summer winds north of the New Siberian Islands were easterly, turning northerly over much of the Laptev Sea. This caused much of the outflow from the Lena to remain on the shelf in the Laptev Sea. South of the New Siberian Islands winds were significantly weaker. The Siberian Coastal Current normally transports freshwater eastward on the continental shelf south of the New Siberian Islands [Weingartner et al., 1999], though this circulation can reverse, as it did in 1995 [Münchow et al., 1999]. Since the residence time of river water on the shelf is on the order of 3.5 years [Schlosser et al., 1994], most of the freshwater in our samples from the East Siberian Sea is likely to originate from the Lena River (from previous years' discharge that was transported eastward in the coastal current), with some contribution of water from the 2007 river discharge of the Kolyma and Indigirka. Under the strong southeasterly winds predominant in the East Siberian Sea in the summer of 2007, it is this water that is observed in the central and eastern sections, as shown in Figure 1a.

[22] Pacific water is only present in the easternmost stations in 2007 , where it accounts for up to $40 \%$ of the surface layer. However, the meteoric water fraction in 2007 is still considerably larger than that observed in data from 1993 and 1995. Weingartner et al. [1999] hypothesizes that the Siberian Coastal Current is deflected offshore and mixes with Bering Strait inflow at a position that will vary considerably, depending on river outflow and wind conditions. The easterly/southeasterly winds of 2007 would favor upwelling and weaken the coastal current, forcing it offshore or possibly even leading to a reversal. This mechanism could effectively allow Pacific-derived waters to flow farther to the west than normal.

[23] 2007 was an unusual year in a modern perspective, with sea ice extent reaching a record minimum. However, many of the IPCC AR4 models predict further reductions in sea ice extent over the next century [Overland and Wang, 2007] — and there are predictions that this may even occur faster than forecast [e.g., Stroeve et al., 2007]. Hitherto, the quantitative use of barium as a tracer for meteoric water has assumed that the ocean was predominantly ice-covered, hence limiting the productivity that leads to its depletion near the surface and the corresponding increase at depth. The retreat of the sea ice cover appears to be bringing about conditions which invalidate this assumption and complicate the use of $\mathrm{Ba}$ as a tracer of river water in the Arctic Ocean.

[24] Acknowledgments. This work was funded by the Natural Environment Research Council through the ASBO IPY consortium grant K. Falkner and M. Alkire acknowledge support from the US NSF Office of Polar Programs under grants 0352984 and 0634122 . We wish to thank the NABOS program and collaborators at AARI for their contributions to the cruise, and the captain and crew of the Viktor Buynitskiy for their assistance.

\section{References}

Aagaard, K., L. K. Coachman, and E. Carmack (1981), On the halocline of the Arctic Ocean, Deep Sea Res., Part A, 28(6), 529-545, doi:10.1016/ 0198-0149(81)90115-1.

Broecker, W. S., et al. (1998), How much deep water is formed in the Southern Ocean?, J. Geophys. Res., 103(C8), 15,833-15,843, doi:10.1029/98JC00248. 
Cooper, L. W., J. W. McClelland, R. M. Holmes, P. A. Raymond, J. J. Gibson, C. K. Guay, and B. J. Peterson (2008), Flow-weighted values of runoff tracers $\left(\delta^{18} \mathrm{O}, \mathrm{DOC}, \mathrm{Ba}\right.$, alkalinity) from the six largest Arctic rivers, Geophys. Res. Lett., 35, L18606, doi:10.1029/2008GL035007.

Dmitrenko, I., S. Kirillov, H. Eicken, and N. Markova (2005), Wind-driven summer surface hydrography of the eastern Siberian shelf, Geophys. Res. Lett., 32, L14613, doi:10.1029/2005GL023022.

Dmitrenko, I. A., S. A. Kirillov, and L. B. Tremblay (2008), The long-term and interannual variability of summer fresh water storage over the eastern Siberian shelf: Implication for climatic change, J. Geophys. Res., 113 C03007, doi:10.1029/2007JC004304.

Ekwurzel, B., P. Schlosser, R. A. Mortlock, R. G. Fairbanks, and J. H. Swift (2001), River runoff, sea ice meltwater, and Pacific water distribution and mean residence times in the Arctic Ocean, J. Geophys. Res., 106(C5), 9075-9092, doi:10.1029/1999JC000024.

Epstein, S., and T. Mayeda (1953), Variation of $\mathrm{O}^{18}$ content of waters from natural sources, Geochim. Cosmochim. Acta, 4(5), 213-224, doi:10.1016/0016-7037(53)90051-9.

Falkner, K. K., R. W. Macdonald, E. C. Carmack, and T. Weingartner (1994), The potential of barium as a tracer of Arctic water masses, in The Polar Oceans and Their Role in Shaping the Global Environment: The Nansen Centennial Volume, Geophys. Monogr. Ser., vol. 85, edited by O. M. Johannessen, R. D. Muench, and J. E. Overland, pp. 63-76, AGU, Washington, D. C.

Guay, C. K., and K. K. Falkner (1997), Barium as a tracer of Arctic halocline and river waters, Deep Sea Res., Part II, 44(8), 1543-1569, doi:10.1016/S0967-0645(97)00066-0.

Guay, C. K., and K. K. Falkner (1998), A survey of dissolved barium in the estuaries of major Arctic rivers and adjacent seas, Cont. Shelf Res., 18(8), 859-882, doi:10.1016/S0278-4343(98)00023-5.

Guay, C. K. H., K. K. Falkner, R. D. Muench, M. Mensch, M. Frank, and R. Bayer (2001), Wind-driven transport pathways for Eurasian Arctic river discharge, J. Geophys. Res., 106(C6), 11,469-11,480, doi:10.1029/2000JC000261.

Münchow, A., T. J. Weingartner, and L. W. Cooper (1999), The summer hydrography and surface circulation of the East Siberian shelf sea, J. Phys. Oceanogr., 29(9), 2167-2182, doi:10.1175/1520-0485(1999)029< 2167:TSHASC $>2.0 . \mathrm{CO} ; 2$

Östlund, H. G., and G. Hut (1984), Arctic Ocean water mass balance from isotope data, J. Geophys. Res., 89(C4), 6373-6381, doi:10.1029/ JC089iC04p06373.

Overland, J. E., and M. Wang (2007), Future regional Arctic sea ice declines, Geophys. Res. Lett., 34, L17705, doi:10.1029/2007GL030808.

Rigor, I., and R. Colony (1997), Sea-ice production and transport of pollutants in the Laptev Sea, 1979-1993, Sci. Total Environ., 202(1-3), 89110, doi:10.1016/S0048-9697(97)00107-1.

Rudels, B., L. G. Anderson, and E. P. Jones (1996), Formation and evolution of the surface mixed layer and halocline of the Arctic Ocean, J. Geophys. Res., 101(C4), 8807-8821, doi:10.1029/96JC00143.
Schlosser, P., D. Bauch, R. Fairbanks, and G. Bönisch (1994), Arctic riverrunoff: Mean residence time on the shelves and in the halocline, Deep Sea Res., Part I, 41(7), 1053-1068, doi:10.1016/0967-0637(94)90018-3.

Schmidt, G. A., G. R. Bigg, and E. J. Rohling (1999), Global seawater oxygen-18 database, http://data.giss.nasa.gov/o18data/, NASA Goddard Inst. for Space Stud., New York, N. Y.

Smith, W. O., Jr., and E. Sakshaug (1990), Polar phytoplankton, in Polar Oceanography, Part B: Chemistry, Biology, and Geology, edited by W. O. Smith Jr., pp. 477-525, Academic, San Diego, Calif.

Stecher, H. A., III, and M. B. Kogut (1999), Rapid barium removal in the Delaware estuary, Geochim. Cosmochim. Acta, 63(7-8), 1003-1012, doi:10.1016/S0016-7037(98)00310-X.

Steele, M., and T. Boyd (1998), Retreat of the cold halocline layer in the Arctic Ocean, J. Geophys. Res., 103(C5), 10,419-10,435, doi:10.1029/ 98JC00580.

Stroeve, J., M. M. Holland, W. Meier, T. Scambos, and M. Serreze (2007), Arctic sea ice decline: Faster than forecast, Geophys. Res. Lett., 34, L09501, doi:10.1029/2007GL029703.

Stroeve, J., M. Serreze, S. Drobot, S. Gearheard, M. Holland, J. Maslanik, W. Meier, and T. Scambos (2008), Arctic sea ice extent plummets in 2007, Eos Trans. $A G U, 89(2)$, doi:10.1029/2008EO020001.

Taylor, J. R., K. K. Falkner, U. Schauer, and M. Meredith (2003), Quantitative considerations of dissolved barium as a tracer in the Arctic Ocean, J. Geophys. Res., 108(C12), 3374, doi:10.1029/2002JC001635.

Weingartner, T. J., S. Danielson, Y. Sasaki, V. Pavlov, and M. Kulakov (1999), The Siberian Coastal Current: A wind- and buoyancy-forced Arctic coastal current, J. Geophys. Res., 104(C12), 29,697-29,713, doi:10.1029/1999JC900161.

Woodgate, R. A., K. Aagaard, R. D. Muench, J. Gunn, G. Björk, B. Rudels, A. T. Roach, and U. Schauer (2001), The Arctic Ocean boundary current along the Eurasian slope and the adjacent Lomonosov Ridge: Water mass properties, transports and transformations from moored instruments, Deep Sea Res., Part I, 48(8), 1757-1792, doi:10.1016/S0967-0637(00)00091-1.

Zhang, J., R. Lindsay, M. Steele, and A. Schweiger (2008), What drove the dramatic retreat of Arctic sea ice during summer 2007?, Geophys. Res. Lett., 35, L11505, doi:10.1029/2008GL034005.

E. P. Abrahamsen and M. P. Meredith, British Antarctic Survey, Natural Environment Research Council, High Cross, Madingley Road, Cambridge CB3 0ET, UK. (epab@bas.ac.uk)

M. B. Alkire and K. K. Falkner, College of Oceanic and Atmospheric Science, Oregon State University, Corvallis, OR 97331-5503, USA.

S. Bacon and S. Torres-Valdes, National Oceanography Centre, European Way, Southampton SO14 3ZH, UK.

V. Ivanov, Scottish Association for Marine Science, Oban PA37 1QA, UK.

S. W. Laxon, Centre for Polar Observations and Modelling, University College London, Gower Street, London WC1E 6BT, UK.

M. J. Leng, NERC Isotope Geosciences Laboratory, British Geological Survey, Keyworth, Nottingham NG12 5GG, UK.

I. Polyakov, International Arctic Research Center, University of Alaska Fairbanks, P.O. Box 757335, Fairbanks, AK 99775-7220, USA. 